\title{
LONG-TERM EFFECTIVENESS AND COST EFFECTIVENESS OF MULTIPLE MYELOMA TREATMENT STRATEGIES FOR ELDERLY TRANSPLANT-INELIGIBLE PATIENTS IN SERBIA DOLGOROČNA USPEŠNOST IN STROŠKOVNA UČINKOVITOST STRATEGIJ ZDRAVLJENJA MULTIPLEGA MIELOMA PRI STAREJŠIH BOLNIKIH, KI NISO PRIMERNI ZA PRESADITEV, V SRBIJI
}

\author{
Durđa VUKIĆEVIĆ ${ }^{*}$, Ursula ROCHAU ${ }^{1}$, Aleksandar SAVIĆ ${ }^{2}$, Monika SCHAFFNER ${ }^{1}$, Milica JEVĐEVIĆ ${ }^{1}$, \\ Igor STOJKOV ${ }^{1}$, Gaby SROCZYNSKI ${ }^{1}$, Wolfgang WILLENBACHER ${ }^{3}$, Beate JAHN ${ }^{1}$, Uwe SIEBERT ${ }^{4,5,6}$
}

1 UMIT - University for Health Sciences, Medical Informatics and Technology, Department of Public Health, Health Services Research and Health Technology Assessment, Institute of Public Health, Medical Decision Making and HTA, Eduard Wallnöfer Zentrum 1, Hall in Tirol, 6060 Austria

${ }^{2}$ University of Novi Sad, Faculty of Medicine, Clinical Center of Vojvodina, Clinic for Hematology, Serbia ${ }^{3}$ Medical University, Internal Medicine V, Hematology and Oncology, Innsbruck, Austria

${ }^{4}$ Area 4 Health Technology Assessment and Bioinformatics,

ONCOTYROL - Center for Personalized Cancer Medicine, Innsbruck, Austria

${ }^{5}$ Harvard Chan School of Public Health, Boston, USA

${ }^{6}$ Massachusetts General Hospital, Institute for Technology Assessment and Department of Radiology, USA

Received: Sep 2, 2019

Accepted: Feb 13, 2020

Original scientific article

\begin{abstract}
Introduction: Evidence on long-term effectiveness and cost effectiveness of treatment sequences for multiple myeloma $(M M)$ is sparse. We used published data and country-specific data to assess the cost effectiveness of four-line treatment

Keywords: multiple myeloma, sequential treatment, long-term effectiveness, cost effectiveness

\section{sequences for elderly transplant-ineligible patients with MM in Serbia.}

Method: We developed a Markov cohort model to compare long-term effectiveness and cost effectiveness of five sequential MM treatment alternatives from the perspective of the national healthcare provider. Effectiveness parameters on progression, mortality and adverse events were extracted from published clinical trials. Costs were based on price lists of the National Health Insurance Fund. We compared life expectancy, costs, and incremental cost-effectiveness ratios among alternative courses of action. The model was analyzed over a lifelong time horizon applying a 3\% annual discount rate for effectiveness outcomes and costs. Robustness of the model was tested in multiple deterministic sensitivity analyses.

Results: The sequences were defined by the frontline treatment: MPT (melphalan-prednisone-thalidomide), MPV (melphalanprednisone-bortezomib), CTD (cyclophosphamide-thalidomide-dexamethasone), VCD (bortezomib-cyclophosphamidedexamethasone) and BP (bendamustine-prednisone). MPV sequence resulted in the highest remaining life expectancy (4.76 life years). Cost-effectiveness analysis resulted in three non-dominated strategies: MPT, VCD, and MPV sequences, with an incremental cost-effectiveness ratio of EUR 35,300 per life-year gained (LYG) for VCD and EUR 47,200/LYG for MPV relative to MPT.

Conclusion: MPV sequence was the most effective in terms of life expectancy for elderly transplant-ineligible MM patients in Serbia. Bortezomib-based strategies would be recommended for the frontline treatment of patients with MM in Serbia if the willingness-to-pay threshold is around EUR 35,000-60,000/LYG.
\end{abstract}

\section{IZVLEČEK}

Ključne besede: multipli mielom, zaporedno zdravljenje, dolgoročna uspešnost, stroškovna učinkovitost
Uvod: O dolgoročni uspešnosti in stroškovni učinkovitosti zaporedij zdravljenja multiplega mieloma (MM) ni veliko dokazov. $\mathrm{Na}$ podlagi objavljenih podatkov in podatkov za posamezne države smo ocenili stroškovno učinkovitost štirih zaporedij zdravljenja starejših bolnikov z MM, ki niso primerni za presaditev, v Srbiji.

Metoda: Za primerjanje dolgoročne uspešnosti in stroškovne učinkovitosti petih alternativ zaporednega zdravljenja MM z vidika nacionalnega izvajalca zdravstvenega varstva smo razvili kohortni model Markova. Parametre uspešnosti glede napredovanja, umrljivosti in neželenih dogodkov smo pridobili iz objavljenih kliničnih preskušanj. Stroški temeljijo na cenikih nacionalnega sklada za zdravstveno zavarovanje. Med različnimi ukrepi smo primerjali pričakovano življenjsko dobo, stroške in mejno razmerje stroškovne učinkovitosti. Model smo analizirali v vseživljenjskem časovnem okviru, pri čemer smo za rezultate uspešnosti in stroške uporabili 3-odstotno letno diskontno stopnjo. Robustnost modela smo preizkusili z več determinističnimi analizami občutljivosti.

Rezultati: Zaporedja so bila opredeljena z zdravljenjem v prvi liniji: MPT (melfalan-prednizon-talidomid), MPV (melfalanprednizon-bortezomib), CTD (ciklofosfamid-talidomid-deksametazon), VCD (bortezomib-ciklofosfamid-deksametazon) in BP (bendamustin-prednizon). Pri zaporedju MPV je bila pričakovana preostala življenjska doba najdaljša (4,76 leta življenja). Pri analizi stroškovne učinkovitosti so bile ugotovljene tri neprevladujoče strategije: zaporedja MPT, VCD in MPV z mejnim razmerjem stroškovne učinkovitosti 35.300 EUR na pridobljeno leto življenja (LYG) za VCD in 47.200 EUR/LYG za MPV glede na MPT.

Sklep: Zaporedje MPV je bilo najuspešnejše v smislu pričakovane življenjske dobe starejših bolnikov z MM, ki niso primerni za presaditev, v Srbiji. Strategije, ki temeljijo na bortezomibu, bi bile priporočljive za zdravljenje bolnikov z MM $v$ prvi liniji $\checkmark$ Srbiji, če je prag pripravljenosti na plačilo približno 35.000-60.000 EUR/LYG. 


\section{INTRODUCTION}

Multiple myeloma $(M M)$ is the second most common hematooncological disease (1) manifested by an uncontrolled monoclonal malignant proliferation of plasma cells in the bone marrow. MM usually affects elderly people, with a median age of about 65 years at diagnosis (2). The global burden of $M M$ is high and rising, mostly due to the increase in incident cases and mortality of $M M$ in middle-income countries (3). In Serbia, MM is a relatively rare disease occurring in around 200 patients per year (4). The disease prognosis has been changed after the introduction of novel treatment agents, such as thalidomide, bortezomib, and lenalidomide. The improved efficacy of these drugs, in terms of progression-free survival (PFS) and overall survival (OS), was presented in several clinical trials (5-7). However, the novel treatment options are also more costly than the standard melphalan-prednisone treatment (8) and the availability and affordability of these medicines is limited in middle-income European economies (9). In Serbia, thalidomide and bortezomib are used in routine clinical practice. Lenalidomide is recommended as an option for relapsed or resistant disease and has been recently approved (3), but it is still not available in treatment centers across the country and is therefore rarely used. In the current situation of economic crisis that Serbia is going through, the healthcare budget resources directed to the treatment of uncommon diseases are limited and require careful weighing of benefits, harms, and costs of treatment alternatives (10). The novel treatment agents are tested in treatment-naive, relapsed, as well as refractory and heavily pretreated patients. However, evidence about the effectiveness of different sequential treatment combinations is sparse and not easily obtainable in prospective clinical studies, as this would require a large study population and a very long follow up. In addition, healthcare policy decision-making and resource allocation have to be based on a systematic and transparent assessment of benefits, harms, and costs, best addressed by the use of decision-analytic modeling combining different sources of evidence (11).

The aim of this study was to assess the clinical effectiveness and cost effectiveness of common sequential treatment pathways for elderly transplant-ineligible patients with $M M$ in Serbia. Furthermore, our goal was to evaluate whether wider use of lenalidomide in everyday clinical practice would change the model-based recommendations.

\section{METHODS}

\subsection{Model Structure}

We adopted the structure of a state-transition Markov model previously developed for the Austrian context (12). To depict treatment patterns in the Serbian healthcare system, important structural changes and parameter adaptations were implemented. To transfer and adapt evidence from another healthcare system to the Serbian national context, we followed a stepwise framework developed for HTA agencies (13). We analyzed the Serbian model over a lifelong time horizon following the established recommendations $(14,15)$ and a national cost-effectiveness guideline (16). The target population consisted of patients with $M M$ ineligible for stem cell transplantation who were 65 years or older. The model was analyzed from the perspective of the Serbian national healthcare provider. We assessed life expectancy (in life years, LYs), costs (in euros, EUR) and the incremental costeffectiveness ratio (ICER; in euros per life year gained (LYG)). In the base-case analysis, we applied a 3\% annual discount rate for both clinical outcomes and costs (17). The model was programmed in the software TreeAge 2016 (TreeAge Software, Inc. Williamstown, MA).

\subsection{Compared Sequential Treatment Strategies}

We compared five sequential treatment pathways commonly used for elderly patients with $M M$ in the Serbian healthcare setting. The treatment pathways were based on the national guideline for the treatment of $M M$ (18), adapted by Serbian clinical experts. As frontline treatment options, we assessed combinations of melphalan, prednisone, and thalidomide (MPT); melphalan, prednisone, and bortezomib (MPV); cyclophosphamide, thalidomide, and dexamethasone (CTD); bortezomib, cyclophosphamide, and dexamethasone (VCD); and bendamustine and prednisone (BP). After progression, patients were switched to the second-line treatment with a different mechanism of action (for example, patients on the first-line thalidomide-based protocols were switched to the bortezomib- or lenalidomide-based regimens in the second line) (Table 1). 
Table 1. Evaluated treatment sequences.

\begin{tabular}{|c|c|c|c|}
\hline \multicolumn{4}{|c|}{ Treatment sequences } \\
\hline $\begin{array}{l}\text { First-line } T x ; \\
\text { Data source }\end{array}$ & $\begin{array}{c}\text { Second-line Tx; } \\
\text { Probability of switching } \\
\text { protocol; Data source }\end{array}$ & $\begin{array}{c}\text { Third-line Tx } \\
\text { Probability of switching } \\
\text { protocol; Data source }\end{array}$ & $\begin{array}{c}\text { Palliative Tx; } \\
\text { Data source }\end{array}$ \\
\hline MPT (19) & $\begin{array}{l}\text { 1. VCD, } 20 \% \text { of cases }(20) \\
\text { 2. VD, } 70 \%(21) \\
\text { 3. RD, } 10 \%(22)\end{array}$ & $\begin{array}{l}\text { 1. RD, } 30 \%(22) \\
\text { 2. BTP, } 40 \%(23) \\
\text { 3. Chemo, } 30 \% \text { * }\end{array}$ & CP $(24,25)$ \\
\hline MPV (26) & $\begin{array}{l}\text { 1. CTD, } 90 \%(27) \\
\text { 2. RD, } 10 \%(22)\end{array}$ & $\begin{array}{l}\text { 1. RD, } 30 \%(22) \\
\text { 2. BTP, } 40 \%(23) \\
\text { 3. Chemo, } 30 \% \text { * }\end{array}$ & CP $(24,25)$ \\
\hline CTD (28) & $\begin{array}{l}\text { 1. MPV, } 30 \%(29) \\
\text { 2. VD, } 60 \%(21) \\
\text { 3. RD, } 10 \%(22)\end{array}$ & $\begin{array}{l}\text { 1. RD, } 30 \%(22) \\
\text { 2. BTP, } 40 \% \\
\text { 3. Chemo, } 30 \% *\end{array}$ & CP $(24,25)$ \\
\hline VCD (30) & $\begin{array}{l}\text { 1. MPT (31) } \\
\text { 2. RD, } 10 \%(22)\end{array}$ & $\begin{array}{l}\text { 1. RD, } 30 \%(22) \\
\text { 2. BTP, } 40 \%(23) \\
\text { 3. Chemo, } 30 \% \text { * }\end{array}$ & CP $(24,25)$ \\
\hline BP (32) & 1. RD, $100 \%(22)$ & $\begin{array}{l}\text { 1. BTP, } 50 \% \text { (23) } \\
\text { 2. Chemo, } 50 \% \text { * }\end{array}$ & CP $(24,25)$ \\
\hline
\end{tabular}

Legend: B-bendamustine; C-cyclophosphamide; Chemo-standard chemotherapy; D-dexamethasone; M-melphalan; P-prednisone; R-lenalidomide; T-thalidomide; Tx-treatment; V-bortezomib; *, Chemotherapy included the following protocols: DCEP (dexamethasone, cyclophosphamide, etoposide, cisplatin) (33, 34), DT-PACE (dexamethasone, thalidomide, cisplatin, doxorubicin, cyclophosphamide, etoposide) $(35,36)$. Patients switched from first-line treatment to different second- and third-line treatment options. The proportion of patients that switched to each particular protocol is presented in Table 1 (\%). Data sources are referenced in parentheses.

As a third-line treatment, patients received a combination of bendamustine, thalidomide, and prednisone (BTP), lenalidomide and dexamethasone (RD) or standard chemotherapy. Palliative treatment consisted of oral administration of low-dose cyclophosphamide and dexamethasone. We assumed administration of a maintenance treatment consisting of daily thalidomide after completion of each treatment protocol, except for $\mathrm{RD}$, which is maintained until progression, and BP recommended for patients with peripheral neuropathy that could deteriorate through thalidomide maintenance.

Figure 1 shows the Markov model with health states and respective state-to-state transitions.

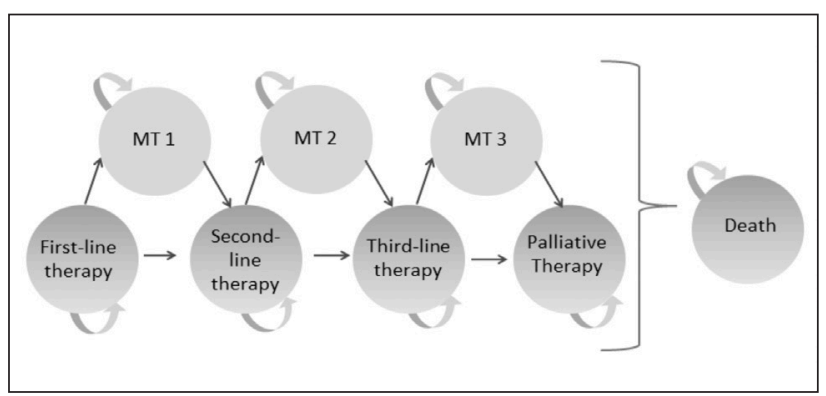

Figure 1. Markov health states and state-to-state transitions. Legend: MT, maintenance treatment; Numbers 1, 2, and 3 indicate the treatment line.
After being diagnosed with $M M$, all patients received first-line treatment. In the case of relapse or recurrence, patients switched to second-line treatment. If the disease did not progress during the treatment, patients transitioned to the maintenance treatment. Patients could die from MM in the second-line and all subsequent treatmnts, while death from other causes was possible in all the states.

\subsection{Natural History and Effectiveness Parameters}

The analyzed cohort consisted of 65-year old transplantineligible patients with MM. Based on clinical expert estimates, $60 \%$ of the population were males. The mortality from causes other than MM was derived from the age- and sex-specific mortality rates reported in the Serbian statistical life tables (37). Guidelinerecommended treatment patterns (18) were discussed with nine clinical experts from Serbia within a Delphi panel and revised based on the real-world clinical practice in terms of exact frequency, dose, and route of drug administration. Efficacy data (PFS and OS) and safety data (frequency of grade 3 and 4 adverse events occurring in more than $5 \%$ of the study population) were extracted from randomized clinical trials. To derive the first-line treatment effectiveness, we fitted a Weibull curve to the weighted proportions of patients who survived without 
progression, extracted from all randomized controlled trials comparing MPT with MP (38). Kaplan Meier curves reported in respective clinical trials (Table 1) were used for the extraction of survival and progression probabilities. Exponential survival models were assumed and excess mortality method was used to derive MM-specific mortality as a difference in overall mortality rates reported in the studies and the mortality from other causes extracted from corresponding life tables. Protocol durations (time to maintenance treatment) were implemented from the guideline recommendations. Probabilities of switching to particular second-line treatment protocols were based on estimates of the Delphi panel (Table 1).

\subsection{Costs}

A bottom-up micro-costing method was applied to analyze healthcare resource consumption and associated costs (39). Healthcare resource utilization during MM treatment was estimated based on the national guideline (18) and clinical experts' estimates. The unit costs of drug acquisition, diagnostic procedures, hospitalization, outpatient care, and injectable drug administration were extracted from the National Health Insurance Fund (NHIF) databases (4042 ) and converted to 2018 euros based on purchasing power parities ( 1 euro=56.3 Serbian dinars) (43). Details on unit costs and cost calculation can be found elsewhere (39).

\subsection{Analyses}

In the base-case analysis, we evaluated five sequential four-line MM treatment strategies in terms of remaining life expectancy and cost effectiveness. In order to assess the robustness of the model, we tested the sensitivity of its results to parameter changes. Based on recommendations of the national cost-effectiveness guideline (16), we applied a $1.5 \%$ discount rate for clinical outcomes while keeping the $3 \%$ discount rate for economic outcomes, and also analyzed the scenario with a $5 \%$ discount rate applied to both health outcomes and costs (44).

The incremental cost-effectiveness ratios (ICERs) for the treatment sequences are strongly dependent on the underlying probabilities to switch from the initial treatment to subsequent treatment options. To assess the impact of probabilities of switching to a particular secondline treatment on the model-based recommendations, we structurally adapted the model to assess the cost effectiveness of all potential first- and second-line treatment combinations, analyzing 11 different sequences. The third-line treatment was kept the same.

As lenalidomide is still not available in institutions across Serbia, we varied second- and third-line probabilities of switching to lenalidomide-based protocols from 0 to 'increased by $100 \%$ ' to account for the possibility of gradually increased administration of lenalidomide in future, once it becomes widely available.
Finally, progression and survival probabilities for thirdline chemotherapy were based on observational studies, because of the lack of randomized controlled trials. Therefore, we analyzed the change in the results if we exclude these treatment options from the analysis.

\subsection{Model Validation}

The face validity of the model was discussed with clinical experts and other decision-analytic modelers. Internal verification of the model was assessed using a thorough examination of parameters, formulas, and codes used in TreeAge by two independent modelers. The health states were mutually exclusive and collectively exhaustive and the rule of symmetrical branching was satisfied (45).

\section{RESULTS}

\subsection{Base-Case Analysis}

The base-case analysis resulted in a remaining life expectancy ranging from 3.70 to $4.76 \mathrm{LYs}$, depending on the treatment sequence (Table 2). The most effective treatment sequence was Starting with MPV with a remaining discounted life expectancy of 4.76 LYs. For comparison, the life expectancy of the general 65-year old population in Serbia is 15.8 years based on the life-table estimates (37).

In the cost-effectiveness analysis, three strategies were identified as non-dominated: Starting with MPT, VCD, and MPV.

Table 2. Discounted base-case analysis results.

\begin{tabular}{lccc}
\hline Strategy & Cost $(€)$ & $\begin{array}{c}\text { Life expectancy } \\
(\text { LYs })\end{array}$ & $\begin{array}{c}\text { ICER } \\
(€ / \text { LYG })\end{array}$ \\
\hline Starting with MPT & 116,500 & 3.70 & - \\
Starting with CTD & 123,400 & 3.41 & Dom \\
Starting with VCD & 126,700 & 3.99 & 35,300 \\
Starting with MPV & 163,300 & 4.76 & 47,200 \\
Starting with BP & 373,400 & 3.98 & Dom \\
\hline
\end{tabular}

Legend: BP, bendamustine, prednisone; CTD, cyclophosphamide, thalidomide, dexamethasone; Dom, dominated, ICER, incremental cost-effectiveness ratio; LY(s), life year(s); LYG, life year gained; MPT, melphalan, prednisone, thalidomide; MPV, melphalan, prednisone, bortezomib; VCD, bortezomib, cyclophosphamide, dexamethasone; $€$, euro.

\subsection{Scenario and Sensitivity Analyses}

The results of the discount rate variations are presented in Table 3. Non-dominated strategies remained the same as in the base-case analysis, but the ICERs changed, as expected. 
Table 3. Variation of annual discount rates.

\begin{tabular}{|c|c|c|c|c|c|c|}
\hline \multirow{2}{*}{$\begin{array}{l}\text { Discount rate } \rightarrow \\
\text { Strategy }\end{array}$} & \multicolumn{3}{|c|}{$1.5 \%$ for effectiveness; $3 \%$ for costs } & \multicolumn{3}{|c|}{$5 \%$ for effectiveness and costs } \\
\hline & Cost $(€)$ & $\begin{array}{l}\text { Life expectancy } \\
\text { (LYs) }\end{array}$ & ICER (€/LYG) & Cost $(€)$ & $\begin{array}{l}\text { Life expectancy } \\
\text { (LYs) }\end{array}$ & ICER (€/LYG) \\
\hline Starting with MPT & 116,500 & 3.85 & - & 110,500 & 3.51 & - \\
\hline Starting with CTD & 123,400 & 3.53 & Dom & 117,900 & 3.25 & Dom \\
\hline Starting with VCD & 126,700 & 4.16 & 32,500 & 121,800 & 3.77 & 43,800 \\
\hline Starting with MPV & 163,300 & 5.01 & 43,100 & 156,100 & 4.47 & 49,600 \\
\hline Starting with BP & 373,400 & 4.15 & Dom & 351,800 & 3.77 & Dom \\
\hline
\end{tabular}

Legend: BP, bendamustine, prednisone; CTD, cyclophosphamide, thalidomide, dexamethasone; Dom, dominated; Ext Dom, extended dominated; ICER, incremental cost-effectiveness ratio; LY(s), life year(s); LYG, life year gained; MPT, melphalan, prednisone, thalidomide; MPV, melphalan, prednisone, bortezomib; VCD, bortezomib, cyclophosphamide, dexamethasone; $€$, euro

When we analyzed 11 treatment sequences assuming an equal likelihood of switching to second-line treatment options, four sequences were identified as non-dominated: 1. frontline MPT and VD after treatment failure $(M P T \rightarrow V D)$, 2. $M P T \rightarrow V C D, 3 . M P V \rightarrow C T D$ and $4 . M P V \rightarrow R D$ (Figure 2 ).
When varying the probability to switch to lenalidomide protocols, non-dominated strategies remained the same (Table 4).

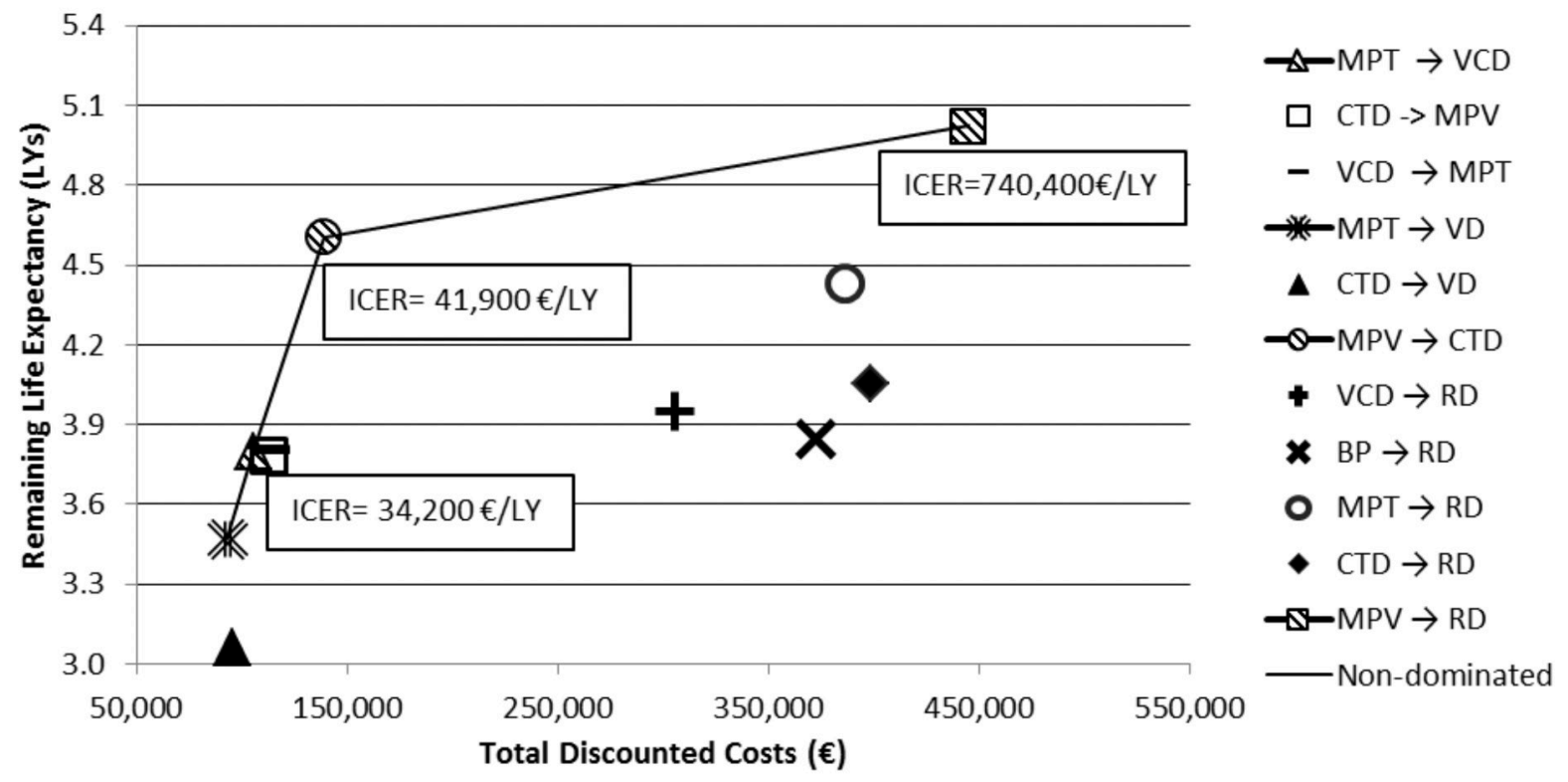

Figure 2. Sensitivity analysis - Cost-effectiveness plane. Sequences defined by the combinations of first- and second-line treatment. The thick line is the cost-effectiveness frontier. 
Table 4. Sensitivity analysis results - varying probability of switching to the lenalidomide-based treatment options.

\begin{tabular}{|c|c|c|c|c|c|c|c|c|c|c|c|c|}
\hline \multirow[t]{2}{*}{ Strategy } & \multicolumn{3}{|c|}{ Without RD options } & \multicolumn{3}{|c|}{$\begin{array}{c}\text { Probability of switching to } \\
\text { RD increased by } 20 \%\end{array}$} & \multicolumn{3}{|c|}{$\begin{array}{l}\text { Probability of switching } \\
\text { to RD increased by } 50 \%\end{array}$} & \multicolumn{3}{|c|}{$\begin{array}{l}\text { Probability of switching to } \\
\text { RD increased by } 100 \% \\
\text { (i.e., doubled) }\end{array}$} \\
\hline & Cost $(€)$ & $\begin{array}{l}\text { Life } \\
\text { expect- } \\
\text { ancy } \\
\text { (LYs) }\end{array}$ & $\begin{array}{c}\text { ICER } \\
(€ / L Y G)\end{array}$ & Cost $(€)$ & $\begin{array}{l}\text { Life } \\
\text { expect- } \\
\text { ancy } \\
\text { (LYs) }\end{array}$ & $\begin{array}{c}\text { ICER } \\
(€ / L Y G)\end{array}$ & Cost $(€)$ & $\begin{array}{l}\text { Life } \\
\text { expect- } \\
\text { ancy } \\
\text { (LYs) }\end{array}$ & $\begin{array}{c}\text { ICER } \\
(€ / L Y G)\end{array}$ & Cost $(€)$ & $\begin{array}{l}\text { Life } \\
\text { expect- } \\
\text { ancy } \\
\text { (LYs) }\end{array}$ & $\begin{array}{l}\text { ICER }(€ / \\
\text { LYG) }\end{array}$ \\
\hline Starting with MPT & 73,000 & 3.63 & - & 124,700 & 3.71 & - & 137,400 & 3.73 & - & 160,300 & 3.77 & - \\
\hline Starting with CTD & 76,900 & 3.29 & Dom & 132,800 & 3.43 & Dom & 147,300 & 3.47 & Dom & 174,200 & 3.54 & Dom \\
\hline Starting with VCD & 82,800 & 3.89 & 36,900 & 136,400 & 4.00 & 39,800 & 151,400 & 4.03 & 46,500 & 178,800 & 4.09 & Ext Dom \\
\hline Starting with MPV & 112,900 & 4.68 & 38,000 & 174,100 & 4.77 & 48,700 & 190,600 & 4.80 & 51,000 & 220,200 & 4.84 & 55,800 \\
\hline Starting with BP* & 373,400 & 3.98 & Dom & 373,400 & 3.98 & Dom & 373,400 & 3.98 & Dom & 373,400 & 3.98 & Dom \\
\hline
\end{tabular}

Legend: BP, bendamustine, prednisone; CTD, cyclophosphamide, thalidomide, dexamethasone; Dom, dominated; ICER, incremental cost-effectiveness ratio; LY(s), life year(s); LYG, life year gained; MPT, melphalan, prednisone, thalidomide; MPV, melphalan, prednisone, bortezomib; VCD, bortezomib, cyclophosphamide, dexamethasone; $€$, euro *BP had a $100 \%$ probability of switching to lenalidomide-based treatment in the base-case analysis; thus the results remained the same.

An additional analysis was performed to assess robustness of the results if we assume no use of chemotherapy as a third-line treatment option. In this case, life expectancies and costs of the strategies were notably higher (Table 5). The strategies remaining non-dominated were the MPT sequence and the MPV sequence with an ICER of EUR $55,800 /$ LY.

Table 5. Sensitivity analysis - ranking of the sequences when excluding the third-line chemotherapy.

\begin{tabular}{lccc}
\hline Strategy & Cost $(€)$ & $\begin{array}{c}\text { Life expectancy } \\
(\text { LYs })\end{array}$ & $\begin{array}{c}\text { ICER } \\
(€ / \text { LYG })\end{array}$ \\
\hline Starting with MPT & 210,200 & 4.40 & - \\
Starting with CTD & 223,100 & 4.16 & Dom \\
Starting with VCD & 251,100 & 4.92 & Ext Dom \\
Starting with MPV & 266,000 & 5.53 & 55,800 \\
Starting with BP & 390,200 & 4.92 & Dom \\
\hline
\end{tabular}

Legend: BP, bendamustine, prednisone; CTD, cyclophosphamide, thalidomide, dexamethasone; Dom, dominated; Ext Dom, extended dominated; ICER, incremental cost-effectiveness ratio; $L Y(s)$, life year(s); MPT, melphalan, prednisone, thalidomide; MPV, melphalan, prednisone, bortezomib; VCD, bortezomib, cyclophosphamide, dexamethasone; $€$, euro.

\section{DISCUSSION}

Based on the results of our analysis, the sequence with frontline MPV provides the most beneficial outcome in terms of life expectancy. The treatment sequences starting with bortezomib-based protocols were cost effective for the treatment of transplant-ineligible elderly patients with $M M$ in Serbia compared to thalidomide- and bendamustine-based protocols, if the willingness-to-pay (WTP) threshold is around EUR 35,000-60,000/LYG. A more detailed assessment of the compared strategies, taking into account first- and second-line treatment combinations, resulted in four non-dominated strategies: $M P T \rightarrow V D, M P T \rightarrow V C D, M P V \rightarrow C T D, M P V \rightarrow R D$. Our analysis shows that, if the NHIF is willing to pay around EUR 40,000/ LYG, the options starting with MPV should be favored in the treatment of elderly patients with MM. Keeping in mind that the annual gross domestic product per capita (GDP) in Serbia in 2017 (the last reference year) was EUR 10,700 , the implementation of the MPV $\rightarrow$ CTD sequence might be considered cost effective from the country's perspective (43). The World Health Organization considers an intervention cost effective if its cost per disabilityadjusted life-year averted (DALY) is less than three times a country's annual GDP per capita (46). We were unable to calculate DALYs due to the lack of country-specific and detailed disease-specific disability weights. However, we can assume that the MPV $\rightarrow$ RD sequence, with an ICER of over EUR 700,000/LYG, would not be considered cost effective in Serbia.

A systematic literature review that assessed the cost effectiveness of bortezomib-based options for treatment of $M M$, reported that the bortezomib-based regimens were cost effective in most of the published reports (47). 
However, the cost-effectiveness reports assessed the health-economic impact of bortezomib-based regimens considering only one treatment line, as a first-line treatment or after relapse (47). Only one study analyzed the lifelong sequential $M M$ treatment. Based on this study, the sequence potentially providing better survival outcomes in a group of elderly patients in the Dutch setting was thalidomide $\rightarrow$ lenalidomide $\rightarrow$ bortezomib (48).

The decision-analytic model that evaluated the cost utility of different first-line MM treatments in transplantineligible patients from the US perspective identified the MPV treatment as cost saving in comparison to MPT and melphalan, prednisone and lenalidomide with lenalidomide maintenance (49). However, it must be noted that thalidomide is available only at a patent-protected price in the US, while in Serbia a generic drug is available at a much lower price than bortezomib (EUR 12 vs. EUR 655 per unit).

Like all decision-analytic modeling studies, our study has several limitations, since the model development required several assumptions to be made. The model was constructed based on the Serbian national guideline recommendations and Serbian clinical experts' opinions. However, the results of the Delphi panel implied that different treatment pathways might be used across different institutions and among clinical experts in Serbia. Thus the results of our analysis might not be exhaustive enough to cover all treatment-related issues in daily clinical routine. Therefore, it would be important to confirm our findings by parameterizing the model with real-world effectiveness data. Furthermore, we systematically searched for the studies that match the guideline-recommended treatment patterns used in Serbia. However, the drug dosing and frequency and route of administration were not always perfectly matched. Survival estimates extracted from trials were modified to disease-specific survival estimates, and Serbian lifetables were applied to simulate the life-expectancy of the model population. This challenging task required complex modeling and a number of assumptions; still, it allowed us to adjust the outcomes of international trials to a specific country population. After patients progressed, we assumed the effectiveness of the subsequent treatment to be independent of the type of prior treatments. This might not be the case in the real world, since drugs with a common mechanism of action may also have similar resistance pathways. However, the patients in our analysis were assigned to a treatment utilizing a different mechanism of action after failure, except for the sequence assuming switching from thalidomidebased protocols to lenalidomide, which was found to be unaffected by previous thalidomide therapy (50). Finally, our model did not consider the quality of life of patients on different treatments, because the evidence was sparse and the implementation of existing data would diminish the robustness of our results. Further research should address the gap in treatment-specific utility estimates, which will provide a solid basis for cost-utility analysis.

The comparison of benefits, harms, and costs of relevant alternatives is stressed as a necessity for healthcare policy decision making in the European Union (51) as well as in Serbia $(52,53)$. Our analysis provides an insight into a daily clinical routine and commonly used treatment pathways and synthesizes the data from different sources in order to assess the clinical and economic impact of lifelong MM treatment in Serbia.

\section{CONCLUSION}

In conclusion, sequential MM treatment with frontline MPV achieves the highest remaining life expectancy for the elderly transplant-ineligible population. This treatment sequence can be considered cost-effective from the Serbian health care perspective if the WTP threshold ranges from EUR 35,000-60,000/LYG.

\section{CONFLICTS OF INTEREST}

The authors declare that no conflicts of interest exist.

\section{FUNDING}

The study was financed by Erasmus Mundus Western Balkans (ERAWEB), a project funded by the European Commission.

\section{ETHICAL APPROVAL}

Ethical approval was not required as patients were not included in the study.

\section{REFERENCES}

1. Kazandjian D. Multiple myeloma epidemiology and survival: a unique malignancy. Semin Oncol. 2016;43(6):676-81. doi: 10.1053/j. seminoncol.2016.11.004.

2. Rajkumar SV. Multiple myeloma: 2018 update on diagnosis, riskstratification, and management. Am J Hematol. 2018;93(8):981-1114. doi: 10.1002/ajh.25117.

3. Cowan AJ, Allen C, Barac A, Basaleem H, Bensenor I, Curado MP, et al. Global burden of multiple myeloma: a systematic analysis for the global burden of disease study 2016. JAMA Oncology. 2018;4(9):1221-7. doi: 10.1001/jamaoncol.2018.2128. 
4. Ferlay J, Colombet M, Soerjomataram I, Dyba T, Randi G, Bettio M, et al. Cancer incidence and mortality patterns in Europe: Estimates for 40 countries and 25 major cancers in 2018. Eur J Cancer. 2018;103:35687. doi: 10.1016/j.ejca.2018.07.005.

5. Kapoor P, Rajkumar SV, Dispenzieri A, Gertz MA, Lacy MQ, Dingli D, et al. Melphalan and prednisone versus melphalan, prednisone and thalidomide for elderly and/or transplant ineligible patients with multiple myeloma: a meta-analysis. Leukemia. 2011;25(4):689-96. doi: 10.1038/leu.2010.313.

6. Mateos MV, Richardson PG, Schlag R, Khuageva NK, Dimopoulos MA, Shpilberg O, et al. Bortezomib plus melphalan and prednisone compared with melphalan and prednisone in previously untreated multiple myeloma: updated follow-up and impact of subsequent therapy in the phase III VISTA trial. J Clin Oncol. 2010;28(13):2259-66. doi: 10.1200/jco.2009.26.0638.

7. Palumbo A, Hajek R, Delforge M, Kropff M, Petrucci MT, Catalano $\mathrm{J}$, et al. Continuous lenalidomide treatment for newly diagnosed multiple myeloma. N Engl J Med. 2012;366(19):1759-69. doi: 10.1056/ NEJMoa1112704.

8. Gaultney JG, Uyl-de Groot CA. Efficient allocation of novel agents in multiple myeloma: a work in progress. Oncologist. 2013;18(1):5-7. doi: 10.1634/theoncologist.2012-0484.

9. Jakovljević M. Oncology monoclonal antibodies expenditure trends and reimbursement projections in the emerging Balkan market. Economics Health economics and therapeutic pathways. 2014;15(1):2732. doi: 10.7175/fe.v15i1.909.

10. Jakovljevic MB, Jovanovic M, Lazic Z, Jakovljevic V, Djukic A, Velickovic R, et al. Current efforts and proposals to reduce healthcare costs in Serbia. Serb J Experiment Clin Res. 2011;12(4):161-3. doi: 10.5937/sjecr1104161J.

11. Siebert U. When should decision-analytic modeling be used in the economic evaluation of health care? Eur J Health Economics. 2003;4(3):143-50.

12. Rochau U, Vukićević $Ð$, Angerer S, Schaffner M, Qerimi V, ConradsFrank $A$, et al. Cost-effectiveness analysis on sequential treatment regimens for elderly patients with multiple myeloma. In: 11th DGGÖ Jahrestagung. Augsburg, 2019.

13. Siebert U. Using decision-analytic modelling to transfer international evidence from health technology assessment to the context of the German health care system. GMS Health Technol Assess. 2005;1:Doc03.

14. Siebert U, Alagoz O, Bayoumi AM, Jahn B, Owens DK, Cohen DJ, et al. State-transition modeling: a report of the ISPOR-SMDM Modeling Good Research Practices Task Force-3. Med Decis Making. 2012;32(5):690700. doi: $10.1177 / 0272989 \times 12455463$.

15. Caro JJ, Briggs AH, Siebert U, Kuntz KM. Modeling good research practices--overview: a report of the ISPOR-SMDM Modeling Good Research Practices Task Force-1. Med Decis Making. 2012;32(5):667-77. doi: $10.1177 / 0272989 \times 12454577$.

16. Novaković T, Tešić D, Stefanović D, Medić G, Sovtić D. Vodič za farmakoekonomske evaluacije. Belgrade: Savez farmaceutskih udruženja Srbije, 2011.

17. Smith $\mathrm{DH}$, Gravelle $\mathrm{H}$. The practice of discounting in economic evaluations of healthcare interventions. Int J Technol Assess Health Care. 2001;17(2):236-43.

18. Serbian Myeloma Group. Multipli mijelom - dijagnostički i terapijski vodič. Accessed March 10th, 2019 at: http://smg.rs/download/SMG_ vodic_2015.pdf.

19. Palumbo A, Bringhen S, Liberati AM, Caravita T, Falcone A, Callea V, et al. Oral melphalan, prednisone, and thalidomide in elderly patients with multiple myeloma: updated results of a randomized controlled trial. Blood. 2008;112(8):3107-14. doi: 10.1182/blood-2008-04-149427.
20. Kropff M, Bisping G, Schuck E, Liebisch P, Lang N, Hentrich M, et al. Bortezomib in combination with intermediate-dose dexamethasone and continuous low-dose oral cyclophosphamide for relapsed multiple myeloma. $\mathrm{Br} \mathrm{J}$ Haematol. 2007;138(3):330-7. doi: 10.1111/j.13652141.2007.06656.x.

21. Hjorth M, Hjertner O, Knudsen LM, Gulbrandsen N, Holmberg E, Pedersen PT, et al. Thalidomide and dexamethasone vs. bortezomib and dexamethasone for melphalan refractory myeloma: a randomized study. Eur J Haematol. 2012;88(6):485-96. doi: 10.1111/j.16000609.2012.01775.x.

22. Stadtmauer EA, Weber DM, Niesvizky R, Belch A, Prince MH, San Miguel $J F$, et al. Lenalidomide in combination with dexamethasone at first relapse in comparison with its use as later salvage therapy in relapsed or refractory multiple myeloma. Eur J Haematol. 2009;82(6):426-32. doi: 10.1111/j.1600-0609.2009.01257.x.

23. Ponisch W, Rozanski M, Goldschmidt H, Hoffmann FA, Boldt T, Schwarzer A, et al. Combined bendamustine, prednisolone and thalidomide for refractory or relapsed multiple myeloma after autologous stem-cell transplantation or conventional chemotherapy: results of a Phase I clinical trial. Br J Haematol. 2008;143(2):191-200. doi: 10.1111/j.1365-2141.2008.07076.x.

24. Hajek R, Masszi T, Petrucci MT, Palumbo A, Rosinol L, Nagler A, et al. A randomized phase III study of carfilzomib vs low-dose corticosteroids with optional cyclophosphamide in relapsed and refractory multiple myeloma (FOCUS). Leukemia. 2017;31(1):107-14. doi: 10.1038/ leu.2016.176.

25. de Weerdt O, van de Donk NW, Veth G, Bloem AC, Hagenbeek A, Lokhorst HM. Continuous low-dose cyclophosphamide-prednisone is effective and well tolerated in patients with advanced multiple myeloma. Neth J Med. 2001;59(2):50-6.

26. San Miguel JF, Schlag R, Khuageva NK, Dimopoulos MA, Shpilberg O, Kropff $M$, et al. Bortezomib plus melphalan and prednisone for initial treatment of multiple myeloma. N Engl J Med. 2008;359(9):906-17. doi: 10.1056/NEJMoa0801479.

27. Dmoszynska A, Walter-Croneck A, Hus I, Grzasko N, Manko J, Jedrzejczak WW, et al. The efficacy and safety of the low-thalidomide dose CTD (cyclophosphamide, thalidomide, dexamethasone) regimen in patients with multiple myeloma--a report by the Polish Myeloma Study Group. Leuk Res. 2010;34(10):1330-5. doi: 10.1016/j. leukres.2010.05.003.

28. Morgan GJ, Davies FE, Gregory WM, Russell NH, Bell SE, Szubert AJ, et al. Cyclophosphamide, thalidomide, and dexamethasone (CTD) as initial therapy for patients with multiple myeloma unsuitable for autologous transplantation. Blood. 2011;118(5):1231-8. doi: 10.1182/ blood-2011-02-338665.

29. Petrucci MT, Levi A, Bringhen S, Scotti S, Gentilini F, Russo S, et al. Bortezomib, melphalan, and prednisone in elderly patients with relapsed/refractory multiple myeloma: a multicenter, open label phase 1/2 study. Cancer. 2013;119(5):971-7. doi: 10.1002/cncr.27820.

30. Kumar SK, Therneau TM, Gertz MA, Lacy MQ, Dispenzieri A, Rajkumar SV, et al. Clinical course of patients with relapsed multiple myeloma. Mayo Clin Proc. 2004;79(7):867-74. doi: 10.1016/s0025-6196(11)621526.

31. Palumbo A, Avonto I, Bruno B, Ambrosini MT, Bringhen S, Cavallo F, et al. Intravenous melphalan, thalidomide and prednisone in refractory and relapsed multiple myeloma. Eur J Haematol. 2006;76(4):273-7. doi: 10.1111/j.1600-0609.2005.00610.x.

32. Ponisch W, Mitrou PS, Merkle K, Herold M, Assmann M, Wilhelm G, et al. Treatment of bendamustine and prednisone in patients with newly diagnosed multiple myeloma results in superior complete response rate, prolonged time to treatment failure and improved quality of life compared to treatment with melphalan and prednisone--a randomized phase III study of the East German Study Group of Hematology and Oncology (OSHO). J Cancer Res Clin Oncol. 2006;132(4):205-12. doi: 10.1007/s00432-005-0074-4. 
33. Park S, Lee SJ, Jung CW, Jang JH, Kim SJ, Kim WS, et al. DCEP for relapsed or refractory multiple myeloma after therapy with novel agents. Ann Hematol. 2014;93(1):99-105. doi: 10.1007/s00277-0131952-5.

34. Dadacaridou M, Papanicolaou X, Maltesas D, Megalakaki C, Patos P, Panteli K, et al. Dexamethasone, cyclophosphamide, etoposide and cisplatin (DCEP) for relapsed or refractory multiple myeloma patients. J Buon. 2007;12(1):41-4.

35. Gerrie AS, Mikhael JR, Cheng L, Jiang H, Kukreti V, Panzarella T, et al. D(T)PACE as salvage therapy for aggressive or refractory multiple myeloma. Br J Haematol. 2013;161(6):802-10. doi: 10.1111/bjh.12325.

36. Lee CK, Barlogie B, Munshi N, Zangari M, Fassas A, Jacobson J, et al. DTPACE: an effective, novel combination chemotherapy with thalidomide for previously treated patients with myeloma. J Clin Oncol. 2003;21(14):2732-9. doi: 10.1200/jco.2003.01.055.

37. Life table, Serbia. Accessed February 15, 2019 at: http://ec.europa. eu/eurostat/data/database.

38. Buchberger M, Rochau U, Vukićević $Đ$, Willenbacher W, Siebert U. Treatment strategies for elderly patients with newly diagnosed multiple myeloma: a meta-analysis and indirect treatment comparison. Value Health. 2015;18(7):A432. doi: 10.1016/j.jval.2015.09.1031.

39. Vukićević $Đ$, Rochau U, Savić A, Buchberger M, Sroczynski G, Siebert U. Costs of sequential multiple myeloma treatment for elderly transplantineligible patients in the Serbian health care system. Med Pregled. 2019;72(3-4):88-97. doi: https://doi.org/10.2298/MPNS1904088V.

40. National Health Insurance Fund. Rulebook of the reimbursed medicines. Accessed January 13, 2017 at: http://www.rfzo.rs/index. php/osiguranalica/lekovi-info/lekovi-actual.

41. National Health Insurance Fund. Rulebook on prices of laboratory health services. Accessed January 13, 2017 at: http://www.rfzo. rs/download/pravilnici/ugovaranje/Pravilnik\%20o\%20cenama\%20 zdravstvenih\%20usluga\%20na\%20sekundarnom\%20i\%20tercijarnom\%20 nivou\%20zz-14112014.pdf.

42. National Health Insurance Fund. Rulebook on prices of health services in secondary and tertiary health care. Accessed January 13, 2017 at: http://www.rfzo.rs/download/pravilnici/ugovaranje/Pravilnik\%20 o\%20cenama\%20zdravstvenih\%20usluga\%20na\%20sekundarnom\%20 i\%20tercijarnom\%20nivou\%20zz-14112014.pdf

43. Purchasing power parities and related economic indicators. Accessed February 15, 2019 at: http://ec.europa.eu/eurostat/web/purchasingpower-parities/data/database.

44. Attema AE, Brouwer WBF, Claxton K. Discounting in economic evaluations. PharmacoEconomics. 2018;36(7):745-58. doi: 10.1007/ s40273-018-0672-z.

45. Eddy DM, Hollingworth W, Caro JJ, Tsevat J, McDonald KM, Wong JB. Model transparency and validation: a report of the ISPOR-SMDM Modeling Good Research Practices Task Force-7. Med Decis Making. 2012;32(5):733-43. doi: 10.1177/0272989x12454579.

46. Chhatwal J, Mathisen M, Kantarjian H. Are high drug prices for hematologic malignancies justified? A critical analysis. Cancer. 2015;121(19):3372-9. doi: 10.1002/cncr.29512.

47. Chen W, Yang Y, Chen Y, Du F, Zhan H. Cost-effectiveness of bortezomib for multiple myeloma: a systematic review. Clinicoecon Outcomes Res. 2016;8:137-51. doi: 10.2147/ceor.s104195.

48. Blommestein HM, Verelst SG, de Groot S, Huijgens PC, Sonneveld P, Uyl-de Groot CA. A cost-effectiveness analysis of real-world treatment for elderly patients with multiple myeloma using a full disease model. Eur J Haematol. 2016;96(2):198-208. doi: 10.1111/ejh.12571.

49. Garrison LP, Jr., Wang ST, Huang H, Ba-Mancini A, Shi H, Chen K, et al. The cost-effectiveness of initial treatment of multiple myeloma in the U.S. with bortezomib plus melphalan and prednisone versus thalidomide plus melphalan and prednisone or lenalidomide plus melphalan and prednisone with continuous lenalidomide maintenance treatment. Oncologist. 2013;18(1):27-36. doi: 10.1634/ theoncologist.2011-0380.
50. Guglielmelli T, Bringhen S, Rrodhe S, Gay F, Cavallo F, Berruti A, et al. Previous thalidomide therapy may not affect lenalidomide response and outcome in relapse or refractory multiple myeloma patients. Eur J Cancer. 2011;47(6):814-8. doi: 10.1016/j.ejca.2010.12.026.

51. Green T, Bron D, Chomienne C, de Wit TD, de Haas F, Engert A, et al. Costs of haematological disease high and rising. Lancet Haematol. 2016;3(8):e353-4. doi: 10.1016/s2352-3026(16)30074-6.

52. Jakovljević $M B$, Đorđević $N$, Jurišević $M$, Janković $S$. Evolution of the Serbian pharmaceutical market alongside socioeconomic transition. Expert Rev Pharmacoecon Outcomes Res. 2015;15(3):521-30. doi: 10.1586/14737167.2015.1003044.

53. Radovanovic A, Dagovic A, Jakovljević M. Economics of cancer related medical care: estimates worldwide and available domestic evidence. Accessed November 27, 2019 at: https://ssrn.com/abstract=2376348. 